清水 健司・森邦夫・史暁東

\title{
MORPHOLOGY OF NBR SURFACE AND MATRIX IN THE BLOOMING OF STEARAMIDE
}

\section{Kenji SHIMIZU, Kunio MORI, Xiao Dong SHI (Department of Applied Chemistry \& Molecular Science, Faculty of Engineering, Iwate University, 4-3-5 Ueda, Morioka 020- 8551)}

Morphological changes of stearamide(SA) in surface and matrix NBR has been investigated for $10 \mathrm{phr}$ SA-containing NBR samples by reference to the blooming pattern and thermal analysis data of samples. The initial bloom film on the sample surfaces(immediately after mold) was composed of plate crystals. Initial blooming SA crystals become large in order of $18 \% \mathrm{AN}-\mathrm{NBR}<40 \%$ AN-NBR $<29 \%$ AN-NBR. Initial SA particles in NBR matrix become large in order of $18 \%$ AN-NBR $<<29 \%$ AN-NBR $<40 \%$ AN-NBR. In the blooming of $18 \%$ AN-NBR sample, bloom film on surface changed with blooming time from small plates to large plates and again small plates. In $29 \% \mathrm{AN}-\mathrm{NBR}$ and $40 \% \mathrm{AN}-\mathrm{NBR}$. samples, bloom films changed with blooming time from plate to needle crystals. In $18 \%$ AN-NBR sample, SA particles disappeared after $240 \mathrm{~h}$ at $70^{\circ} \mathrm{C}$ from the results of thermal analysis and SEM photographs. In 29\%AN-NBR and 40\%AN-NBR. samples, large SA particles did not change so much in size but small particles decreased their amount to a certain particle size. Those results lead to the conclusion that in viewpoint of surface and matrix morphology, the blooming of SA in NBR does not suit basically to both the supersaturation theory of Williams and free energy slope theory of Nah.

(Received on September 22, 1997)

Key Word: Bloom film photograph, Cut cross section photograph, Stearamide blooming, Various NBR vulcanizates, Thermal analysis, Bloom pattern, Bloom morphology, Stearamide particle size

\section{1. 緒}

言

NBR 加硫物における脂肪酸アミドのブルーム 現象は, Williams の過飽和説 ${ }^{1)} と \mathrm{Nah} の$ 自由工 ネルギー勾配説2)のいずれによっても，それぞれ の重要因子を充分に説明することはできないこと を前報3-5) で示した．本報ではこれに引き続き，

†本報を「脂肪酸アミドのブルーム挙動に関する研究(第 4 報)」とする.
NBR 加硫物における脂肪酸アミドのブルーム理 論の構築のために，ブルーム皮膜とステアリン酸 アミド $(\mathrm{SA})$ 粒子のモルホロジー変化とブルーム 挙動の関係から, 過飽和説および自由エネルギー 勾配説への適合性について再び述べる.

過飽和説では, NBR 加硫物が高濃度の SA(不 安定領域のブルーム)を含む場合，時間とともに 
ゴム中の溶解 SA や過飽和状態 SA は SA 粒子へ 移行して，表面にブルームしないことになる。し たがって，初期に生成したブルーム皮膜は少なく とも成長せず，ブルーム表面のモルホロジーも一 定であり，またゴム中の SA 粒子は時間とともに 大きくなることが予想される。一方，自由エネル ギー勾配説では，NBR 加硫物が過剩の SA を含 む場合，ゴム中の SA 粒子はゴムより圧力を受 け，無応力状態の表面へ移行するので，マトリッ クスの性質に関係なく SA 粒子は時間とともに小 さくなる．また，この場合のブルーム皮膜のモル ホロジーは変化しないか又は一定方向の変化が予 想されるが，本質的な判定因子ではないので，適 合性を決める要因とはならないであろう。更に, 本報ではニトリル含量 (AN \%)の異なる NBR を 用いて SAの溶解性を変化させるが，これは過飽 和説が溶解性の影響を強く受ける挙動を，また自 由エネルギー勾配説がこの影響をほとんど受けな い挙動を示すと考えられるためである。

\section{2. 実験}

\section{1 試薬と材料}

ニトリルゴム $(\mathrm{NBR})$ は日本ゼオン製の $\mathrm{DN} 401 ; \mathrm{AN}=18 \%$, Nipol-1043; $\mathrm{AN}=29 \%$, Nipol-1041; $\mathrm{AN}=40 \%$ な゙ニトリル含量 $(\mathrm{AN}$ \%)の異なるものを使用した. ステアリン酸アミ ド $\left(\mathrm{SA}, \mathrm{mp}=107-8^{\circ} \mathrm{C}\right)$ は前報 ${ }^{3)}$ に準じて合成し たものを使用した。 また硫黄，加硫促進剤および 金属活性剂は市販品を再結晶して使用した。

\section{2 試料の作成とブルーム試験}

ブルーム用の加硫ゴム円形試料は前報3)に従 い, ゴム $10 \mathrm{~g}$ に硫黄 $0.6 \sim 1.0$ 重量部 (以下部), $\mathrm{N}$-シクロヘキシルベンゾチアゾールスルフェン アミド，テトラメチルチウラムジスルフィド，お よび $\mathrm{ZnO}$ を加えて混練し, 更にこれにステアリ ン酸アミド $(\mathrm{SA}) 0$ 又は 10 部を混練して, 網目鎖 濃度 $3 \times 10^{-4} \pm 0.2 \mathrm{~mol} / \mathrm{cm}^{3}$ の NBR 加硫物試料 に調製した。

ブルーム試験は前報3) で述べた厚紙の台座に立 てかけ，これを $70^{\circ} \mathrm{C} の$ 恒温槽に入れて行った。

\section{3 測 定}

ブルーム量は前報3) に従い，ゴム表面の SA ブ ルーム皮膜を剃刀ではぎ取り，付着微結晶を除去 後, 乾燥して重量測定から計算して求めた。

ブルーム表面又は試料切断面の SEM 写真は 5 $\mathrm{mm}$ 角試料表面, 又はゴム切断用高速カッター を用いて試料を切断し，金イオンコーティング(6 $\mathrm{mA}, 8 \mathrm{~min})$ を行い, SEM 測定用試料とした. これを, 走查型電子顕微鏡 (日立製作所侏製の S$2300)$ を使い, 加速電圧 $25 \mathrm{kV}$, 傾斜角度 0 ○で測 定した. DSCの測定は NBR 中に存在するブル 一ム凨の融点を測定するため，セイコ一電子工業 侏製の示差走査熱分析装置 SSC-5200 型を使用し た. 試料は中心付近から約 $7.5 \mathrm{mg}$ を取り出し, セルに入れて測定した。測定は，20〜 $160^{\circ} \mathrm{C}$ の温 度範囲で昇温速度 $20\left({ }^{\circ} \mathrm{C} / \mathrm{min}\right)$ により 2 回行った。

\section{3. 結果}

\section{1 試料の表面と内部のモルホロジー}

Fig. 1，2，および 3 は AN \%の異なる NBR に SA 0 又は 10 部添加して加硫した試料の表 面および切断面の SEM 写真を 400 倍と 3000 倍 で示す．表面の SEM 写真はブルーム皮膜の，ま た切断面の SEM 写真はゴム内部の SA 粒子のモ ルホロジーをそれぞれ観察するために行った。 AN \%は Table 1 に示すように, 溶解度パラメ 一ター $(\delta)$ の差の平方 $\left(\delta_{\mathrm{NBR}}-\delta_{\mathrm{SA}}\right)^{2}(\mathrm{NBR}$ に対す る SA の溶解性の目安)を基準にして選択した. いずれの場合も SA 添加と未添加でゴム表面と切 断ゴム面のモルホロジーは異なり，表面にブルー 厶皮膜又はゴム内部に SA 粒子の存在が認められ る。ブルーム皮膜はいずれも板状 SA 結晶である が，その径は $18 \% \mathrm{AN}<40 \% \mathrm{AN}<29 \% \mathrm{AN}$ の NBR 試料の順序で増加した。ゴム内部の SA 粒子は $18 \% \mathrm{AN}<29 \% \mathrm{AN}<40 \% \mathrm{AN}$ の $\mathrm{NBR}$ 試料の順序で大きくなった。

\section{2 ブルーム皮膜量と表面モルホロジーの関係}

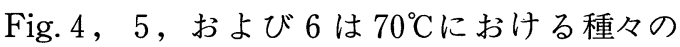
ブルーム過程4)におけるブルーム表面のモルホロ ジーを 500 倍と 3000 倍の SEM 写真で示す。初 期の $18 \% \mathrm{AN}-\mathrm{NBR}$ 試料表面では $10 \sim 20 \mu \mathrm{m}$ 程 度の小さな板状 SA 結晶が集合体としてブルーム 皮膜を形成しているが，ブルーム量の増加ととも

Table 1 Measure in the solibility of stearamid in NBR

\begin{tabular}{c|c|c|c}
\hline NBR & $18 \% \mathrm{AN}$ & $29 \% \mathrm{AN}$ & $40 \% \mathrm{AN}$ \\
\hline$\delta_{\mathrm{NBR}}$ in NBR & 8.75 & 9.6 & 10.5 \\
\hline$\delta_{\mathrm{SA}}$ in SA & \multicolumn{3}{|c}{9.8} \\
\hline$\left(\delta_{\mathrm{NBR}}-\delta_{\mathrm{SA}}\right)^{2}$ & 1.2 & 0.04 & 0.53 \\
\hline
\end{tabular}




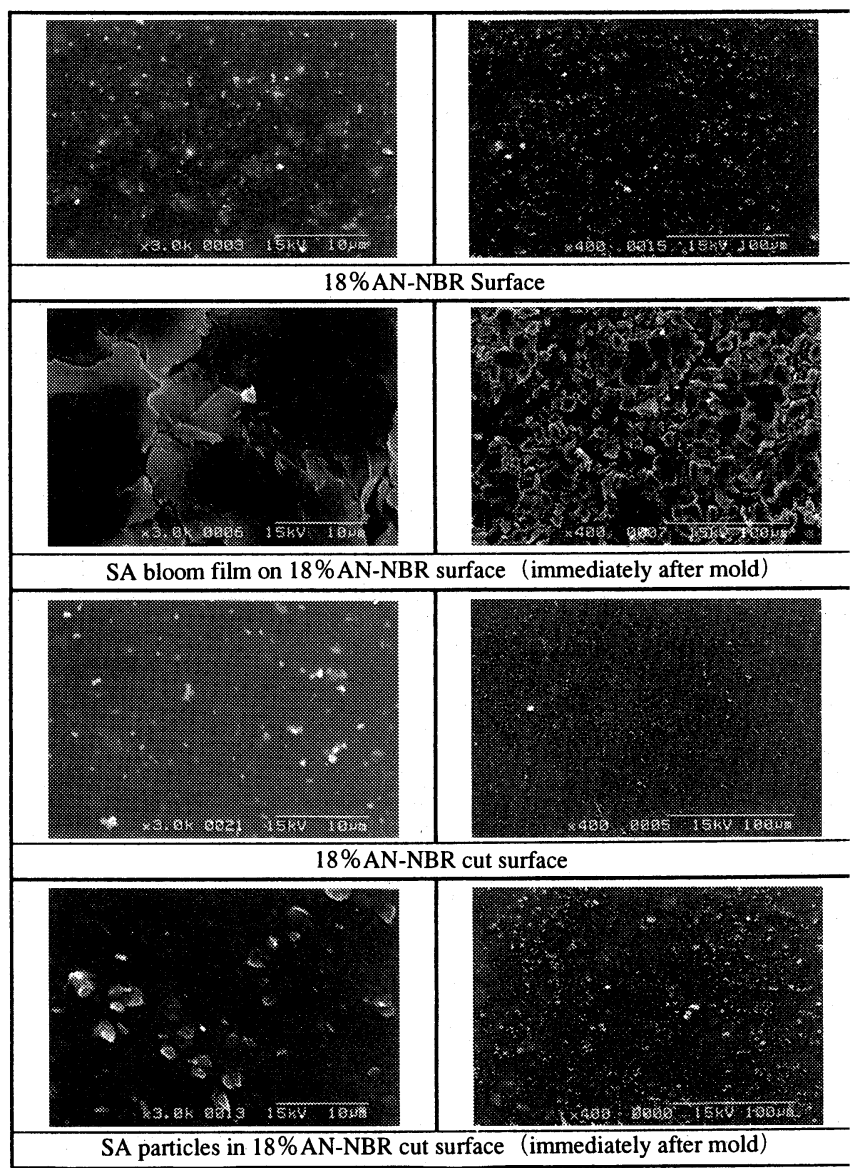

Fig. 1

に板状 SA 結晶は大きく成長して，全体として平 滑な表面に変化した。プラトウ領域 $\left(\right.$ 過程 $\left(V^{4)}\right)$ に おいては平滑な表面が時間とともに針状結晶に変 化した. 更に時間を増加させると, 皮膜量が減少 するが, この時ブルーム表面の板状結晶は表面に 対して垂直方向に反り返る変形結晶に変化した. $29 \% \mathrm{AN}-\mathrm{NBR}$ 試料では, ブルーム過程 III $^{4)} に$ おいて時間とともに板状 SA 結晶が針状結晶に変 化し，プラトウ領域では針状結晶が更に細分化し

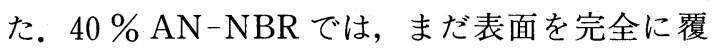
いつくしていない板状 SA 結晶が時間とともに大 きく成長し，ゴム表面を完全に覆い，その後板状 結晶は針状結晶へ変化した。

\subsection{SA 粒子の形状変化と DSC 曲線の関係}

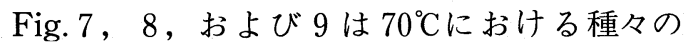

ブルーム過程における切断面の $\mathrm{SA}$ 粒子の変化と 加硫ゴムの DSC 曲線の関係を 1000 倍の SEM 写 真で示す. SEM 写真および図中のA，B，C， D およびE は Fig. $4 ， 5$ ，および 6 のブルーム 時間の測定位置と符号する. SEM 中における球 形の粒子が $\mathrm{SA}$ 粒子であり，図中の $\mathrm{T}_{1}, \mathrm{~T}_{\mathrm{m}}$, お よび $\mathrm{T}_{2}$ はそれぞれ，NBR 加硫ゴム中の $\mathrm{SA}$ 粒 子が溶融し始める温度, 融点および溶融終了温度 である。したがって，これらの值は $\mathrm{T}_{\mathrm{m}}$ を頂点と し, $\mathrm{T}_{1}$ と $\mathrm{T}_{2}$ を両末端值とした, NBR 加硫物中 の SA 粒子分布の目安を示すことになる。すなわ ち， $\mathrm{T}_{1}$ は最も小さい粒子を融解する温度， $\mathrm{T}_{2}$ は 最も大きな粒子が融解する温度である.

$18 \% \mathrm{AN}-\mathrm{NBR}$ 試料は時間とともに $\mathrm{T}_{1}$ がか なり低下するので小さい SA 粒子が多くなり，か 


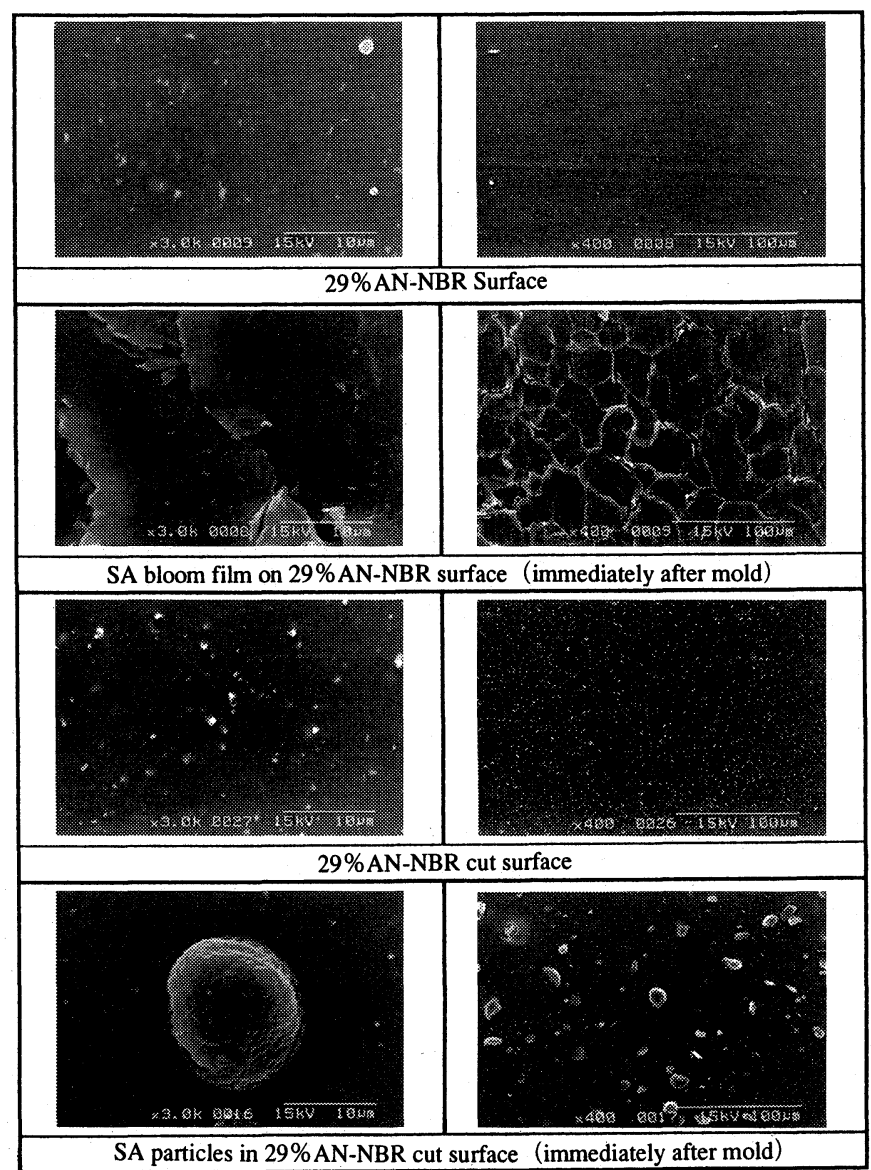

Fig. 2

つ同時に $\mathrm{T}_{\mathrm{m}}$ と $\mathrm{T}_{2}$ も低下するので全体的に $\mathrm{SA}$ 粒子径が小さくなったと判断した. 更に，240 時 間以後には若干の粒子の存在は認められるが, $\mathrm{DSC}$ のピークの強度が小さすぎて $\mathrm{T}_{1}, \mathrm{~T}_{\mathrm{m}}$ およ び $\mathrm{T}_{2}$ は確認できなかった。 $29 \% \mathrm{AN}-\mathrm{NBR}$ で は, 初期の試料は $\mathrm{T}_{1}$ と $\mathrm{T}_{2}$ の差が大きいので広 いSA 粒子分布を形成している。時間とともに $\mathrm{T}_{\mathrm{m}}$ と $\mathrm{T}_{2}$ の差が変化していないので大きい $\mathrm{SA}$ 粒子の分布は変化なく， $\mathrm{T}_{1}$ が高くなるので小さ い SA 粒子が減少した. 更に 169 時間以上になる と $\mathrm{T}_{1}, \mathrm{~T}_{\mathrm{m}}$ および $\mathrm{T}_{2}$ は一定となるので $\mathrm{SA}$ 粒子 径の分布は変化せず一定值を示した. $40 \% \mathrm{AN}$ $\mathrm{NBR}$ でも, 初期の試料は $\mathrm{T}_{2}$ と $\mathrm{T}_{1}$ の差が大き いことから SA 粒子は広い分布からなるが，時間 とともに $\mathrm{T}_{\mathrm{m}}$ と $\mathrm{T}_{2}$ が変化しないので大きい $\mathrm{SA}$
粒子の径はほとんど変化なく， $\mathrm{T}_{1}$ が高くなるの で小さい SA 粒子が減少した。 256 時間以上にな ると $\mathrm{T}_{1}, \mathrm{~T}_{\mathrm{m}}$ および $\mathrm{T}_{2}$ は一定となるので, やは り $\mathrm{SA}$ 粒子径の分布は一定值を示た。

\section{4. 考察}

\section{1 初期試料のブルーム結晶と粒子結晶}

過飽和説においてもまた自由エネルギー勾配論 においても，試料作成時にすでに存在するブルー ム物質についての言及は式の上でも，また現象の 観察についてもほとんど記述されていない6).し かし，この点はNBR に対する脂肪酸アミドのブ ルーム機構を解明するために検討する必要がある と考える. SA を過剩に含む NBR 未加硫ゴムを $160^{\circ} \mathrm{C}$ の加硫過程において SA は一部液滴, 一部 


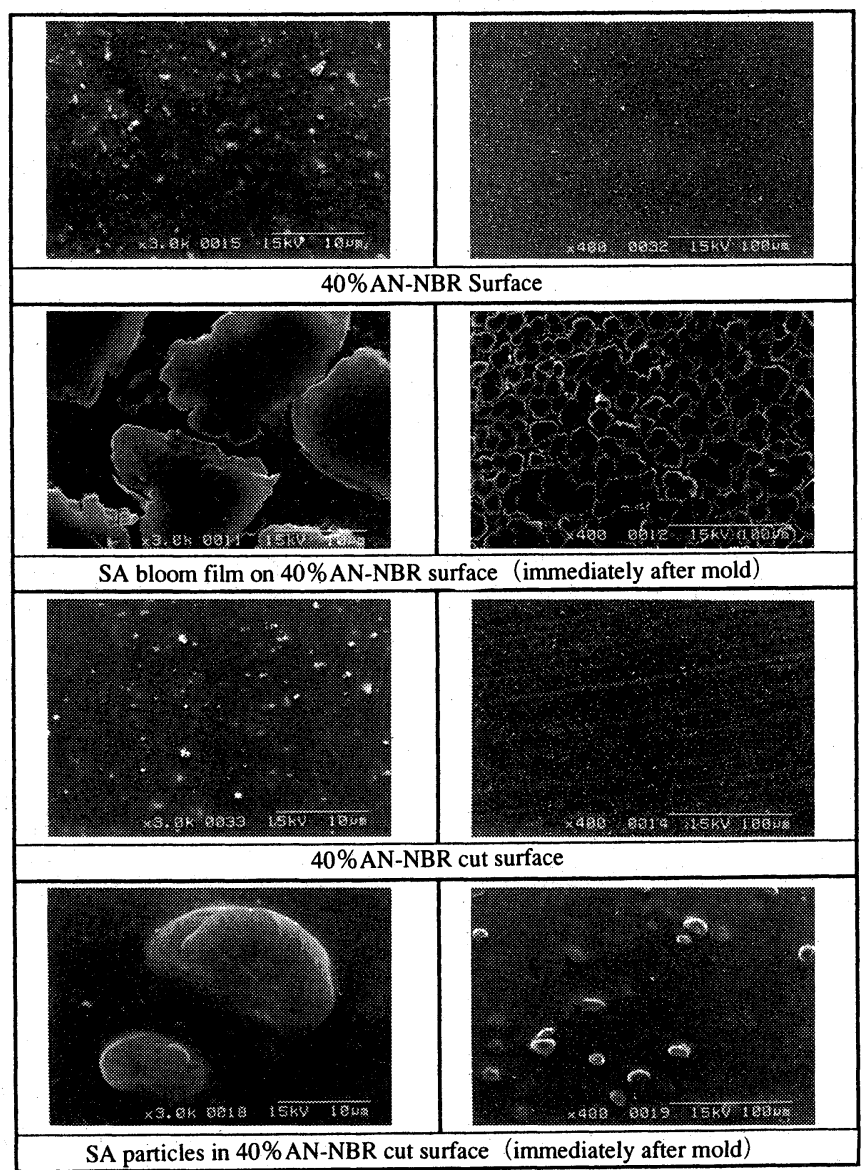

Fig. 3

溶解および一部ゴムと金型の界面に液膜として存 在すると考えられる。液滴》 はマトリックスに溶 解しない過㮃な部分として加硫鎖の形成によって 包み込まれて安定化して存在するであろう．加硫 終了後, NBR 加硫物の温度が下がると, 液滴と 液膜は溶解しているSAの一部(過飽和部分)を取

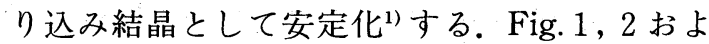
び 3 におけるゴム表面の初期ブルーム皮膜と内部 の SA 粒子の存在は上記のような予測が可能であ ることを示している。

初期ブルーム皮膜量は NBRに対する SA の溶 解性と関係なく，AN \%の増加とともに減少する が(Fig. 4, 5 および 6 )，その様子が初期試料の ブルーム皮膜のモルホロジーからも観察される. SA ブルーム皮膜は AN \%が低い18 AN \% -
NBR 試料の場合, 板状結晶が厚く堆積している が, AN \%が高い 40 AN \%-NBR 試料では，SA 板状結晶の隙間から NBR 表面が見えるほど薄 く, SA 単結晶板が単層で並列していることが分 かる. しかし, SA 結晶の大きさは SAの溶解性 が最も高い $29 \mathrm{AN} \%-\mathrm{NBR}$ 試料において大きく なり，結晶間に吵間はもはや認められない。この ような初期のブルーム皮膜の結晶形状は結晶の核 発生数と関係していると考えられる。溶解性が高 い場合，ブルーム SA 結晶は発生する結晶核が少 ないため大きく成長する，反对に溶解度が低い場 合，核発生数が多いため結晶は小さくなる。この 現象は溶液中からの溶質の結晶核の発生と成長の 一般的な傾向である。

一方, 内部の $\mathrm{SA}$ 粒子は $\mathrm{AN} \%$ の増加ととも 


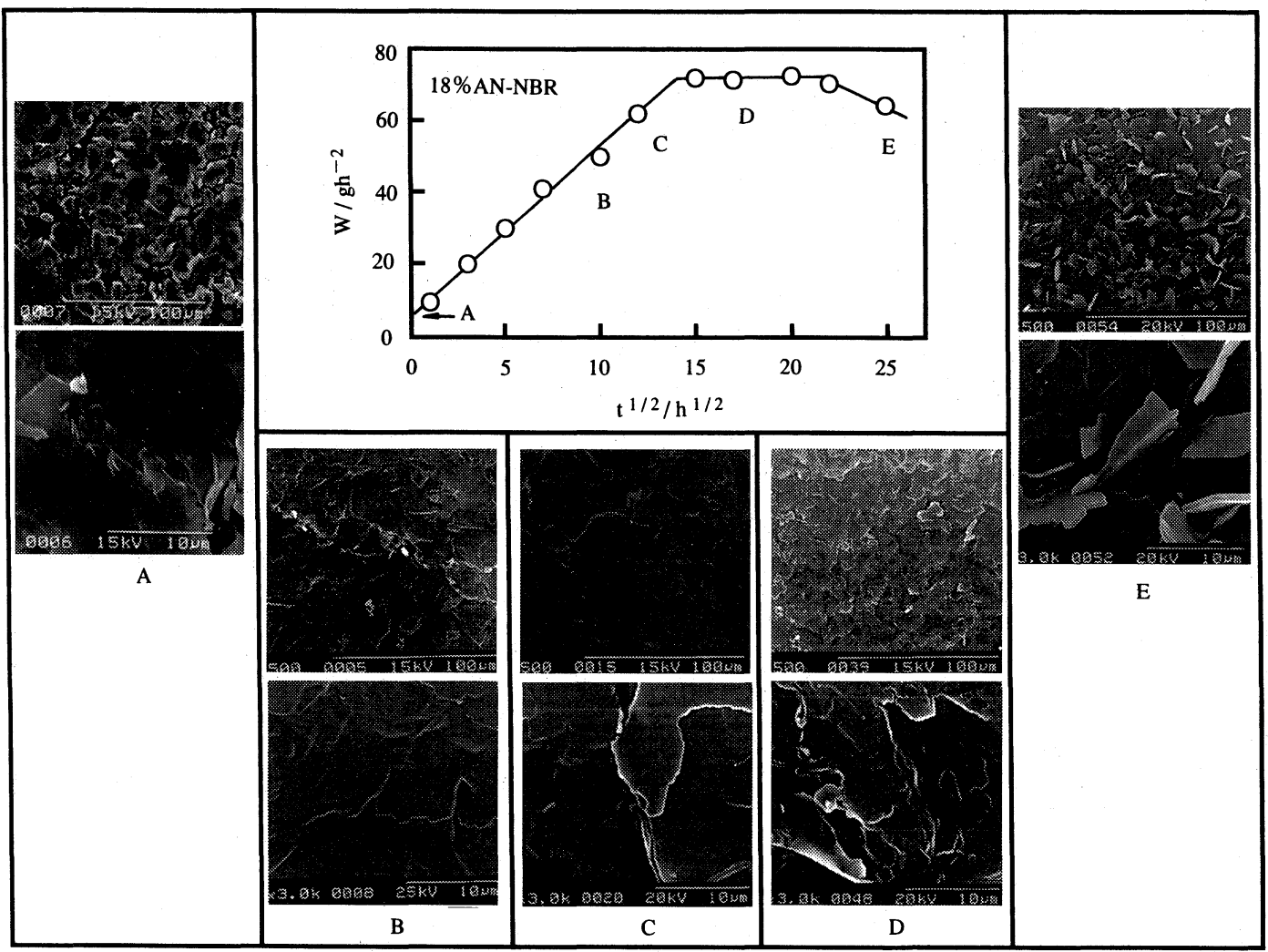

Fig. 4

に大きくなり，ブルーム皮膜のように NBR に対 する SA の溶解性との相関関係は認女られない。 ただし，18\% AN-NBR 試料は SA が最も溶解 しない場合であるので，試料中の SA 結晶粒子が 最も小さいことは理解できる、そしてこの場合は 表面のブルーム結晶と内部の粒子結晶の大きさの 間に相関性は認められる。しかしながら，29\% $\mathrm{AN}-\mathrm{NBR}$ 試料の粒子結晶の大きさと $40 \% \mathrm{AN}-$ NBR 試料のそれは反対であってしかるべきであ る. 実際は後者が前者より大きいため, 表面のブ ルーム結晶と内部の粒子結晶の間にモルホロジー 上の相関関係はない。この結果は後者が前者より 溶解性が小さいにも関わらず，ブルーム量が小さ い事実 ${ }^{3)}$ と関係していると考えられる.

\section{2 ブルーム量とブルーム結晶の変化}

前報3でも記述したように，NBRに対する $\mathrm{SA}$ の溶解性とブルーム速度の全体的および統一 的な相関関係はない.しかし, 明らかにブルーム 表面の SA 結晶の大きさや形状は時間とともに変
化する。過剰な SA の存在下におけるブルームは 過飽和説によれば起こらないはずであるが，溶解 性の異なるいずれの NBR 加硫物においても SA ブルーム皮膜の成長が認められる.この点で NBRにおけるSAのブルームは過飽和説に基本 的に適合しないといえる。 3 種類の NBRについ てブルーム挙動はそれぞれ異なるが，29\% ANNBR 試料と $40 \% \mathrm{AN}-\mathrm{NBR}$ 試料におけるブル 一ム表面のモルホロジ一変化は類似している. 前

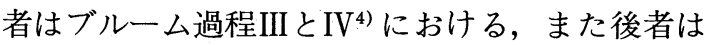
一つのブルーム過程III') におけるブルーム表面の モルホロジ一変化であるが, これらの過程とは関 係なく, 時間とともに板状 SA 結晶から針状結晶 へとブルーム皮膜の結晶形の変化が認められる. このような結晶形の変化は, 必ずしも明らかでは ないが，ゴム中から拡散してくる SA 分子によっ てもたらされると考えられる。しかし，29\% NBRにおけるプラトウ領域 (過程IV4) において も同様の傾向で変化しているが, これはプラトウ 


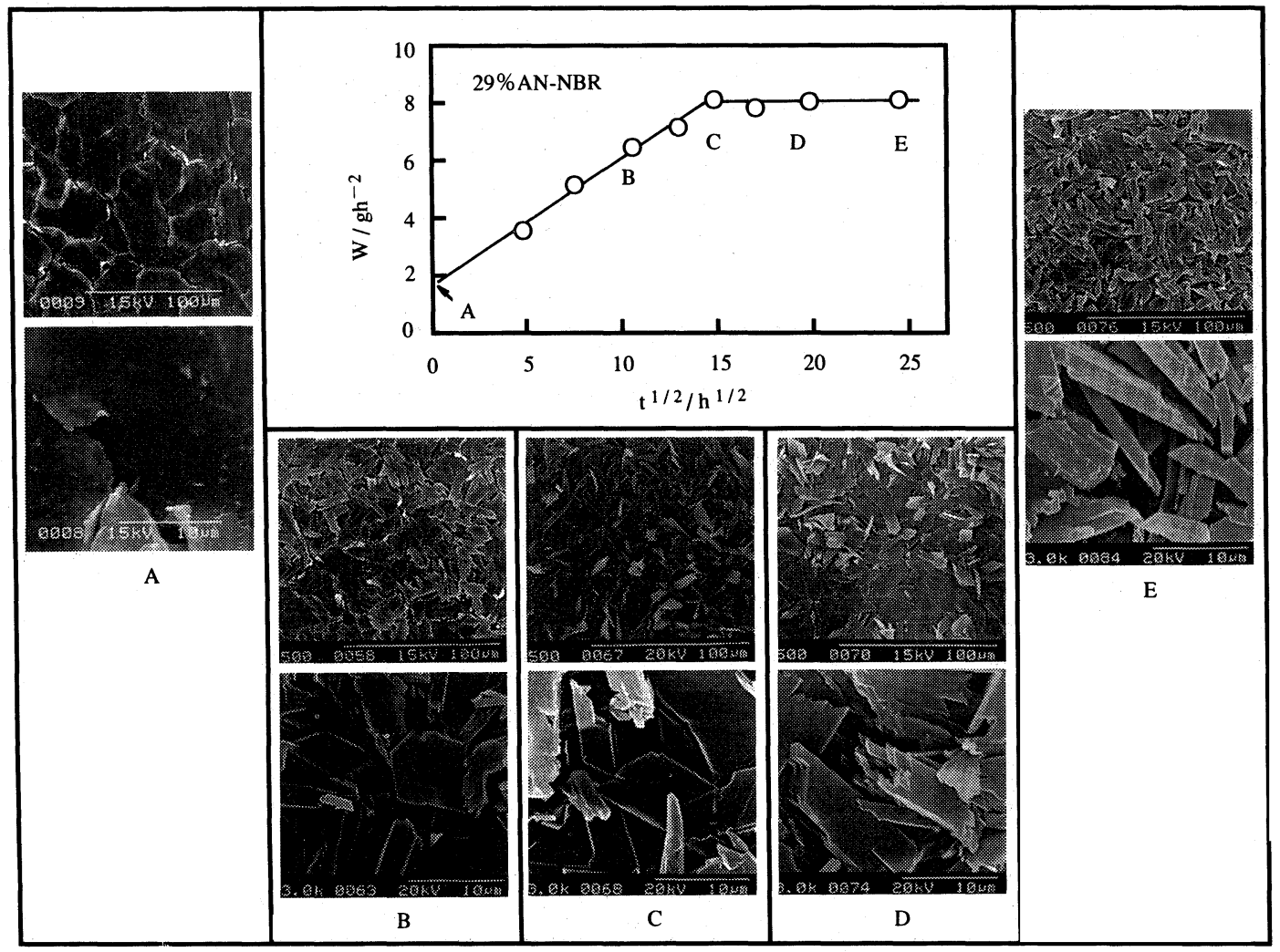

Fig. 5

領域を SA が溶解度以下に達した結果であるとす るか，又は表面のブルーム皮膜と内部の SA の間 に何らかの平衡状態が生じたためと考えるかによ って違ってくる．この場合はブルーム量がまだ充 分少ないため, 溶解度以下に達したという考え方 は支持できない。したがって，ブルーム皮膜とゴ ム中の SA 粒子間で SA 分子の移行に関して平衡 状態が存在し, 結果としてプラトウ領域を示す. しかし SAの移行が絶えず起こっているため表面 モルホロジーが変化したと考えられる．18\% AN-NBR では時間とともに微細板状結晶から大 きな板状結晶に変化し, 再度微細な板状結晶に変 化するが，この場合も，いずれの過程においても $\mathrm{SA}$ 分子がブルーム皮膜とゴム中を移行して生じ た結果と説明できるが，なぜ他の試料のように針 状結晶が生成しないかは不明である。しかし，こ れはマトリックスの違いによる一種の両親媒物質 である SAの存在状態の違いが関係していると考 えるべきであろう。
以上のように, SA ブルーム皮膜は時間ととも に形状および大きさが変化する。このような変化 は従来の過飽和説では多くの部分で説明不可能で ある。自由エネルギー勾配説については予想され る条件を満たしているが，直接的な因子でないの で適合性の可否は判断できない.

\section{3 ゴム中の SA 粒子の変化}

過飽和説において, 高濃度 SA 含有 NBR 試料 は SA ブルーム剤がゴム内部で粒子として存在す ることになるので, ブルームしない場合である. また自由エネルギー勾配論では大きな SA 粒子に 成長すると考えられるから，ブルームしやすい場 合である。このように，高濃度 SA を含有する試 料では両説が相反する結果を示すことになる.

$\mathrm{SA}$ の溶解性の異なる NBR 試料のいずれにおい ても, SA 粒子の存在が認められ，時間とともに ブルーム量が増加する。この点では NBRにおけ る SAのブルームにおける過飽和理論は適用でき ないことになる. $18 \% \mathrm{AN}-\mathrm{NBR}$ 試料は最もブ 


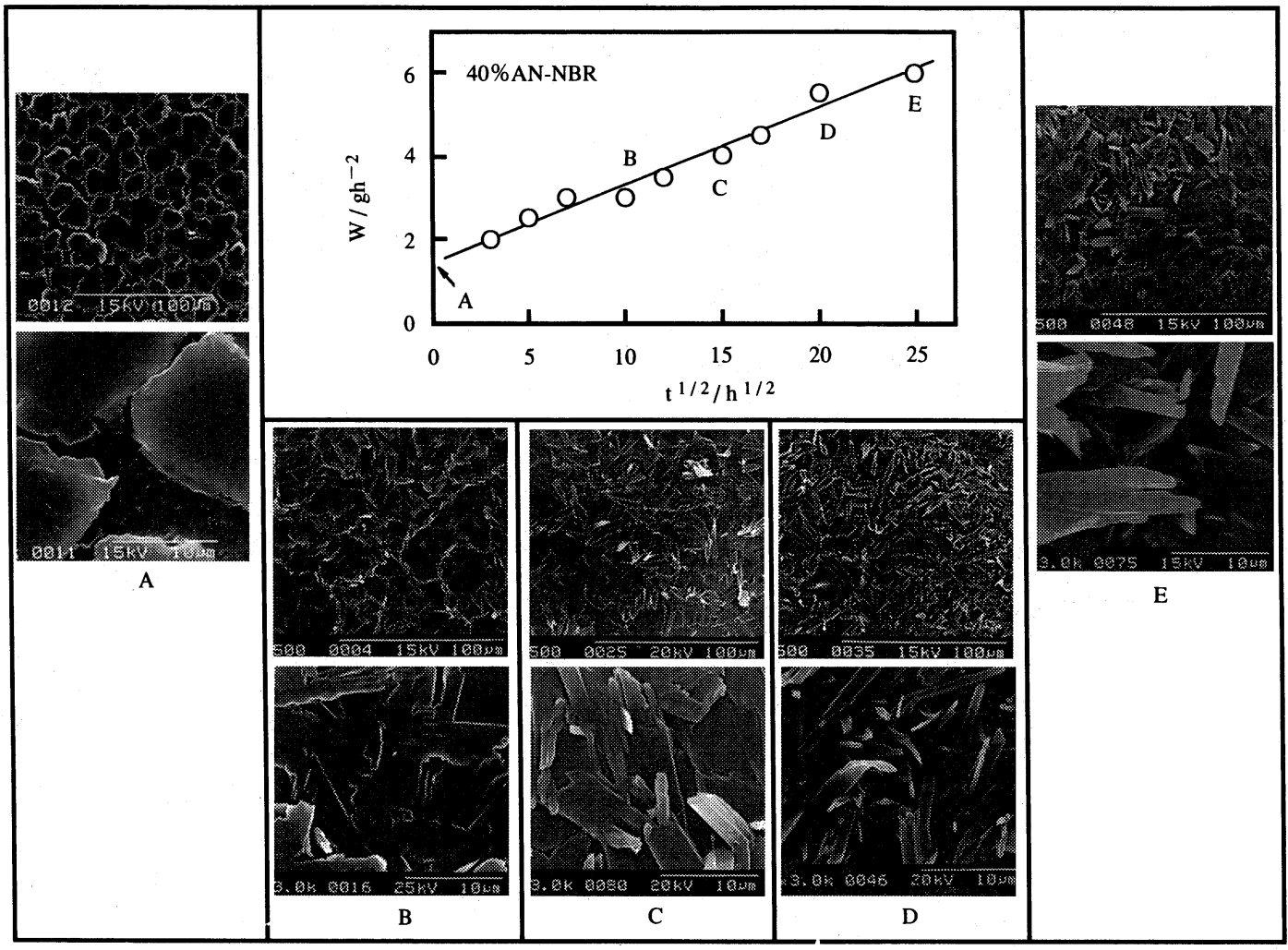

Fig. 6

ルーム速度が高く、ゴム中の溶解度以上の SA は ほとんど NBR 表面へブルームすることはすでに 示した ${ }^{3)}$. Fig. 7 の SEM 写真と DSC データは前 報3)を裏付ける結果となっている. SA 粒子は時 間とともに全体的に減少し，256 時間以上では DSC 測定においてもまたSEM 写真からも，そ の存在は確認できない. SEM 写真中に白く見え る粒子は $\mathrm{SA}$ 粒子ではなく， $\mathrm{ZnO}$ 粒子である。 我々は前報 ${ }^{3)}$ で最も過飽和説に適合性があると判 断した場合でも相分離した SA 粒子がブルームし て, やがて消滅する。この結果はむしろ自由エネ ルギー勾配論を支持する結果に近い。一方， 29 \% AN-NBR 試料また $40 \% \mathrm{AN}-\mathrm{NBR}$ 試料は初 期に小さな $\mathrm{SA}$ 粒子 $\left(\mathrm{T}_{1}\right.$ が低い)を多く含む.そ してこれが時間とともに減少し，256 時間以上で 一定となる。この間 $29 \%$ AN-NBR 試料におけ る大きな $\mathrm{SA}$ 粒子 $\left(\mathrm{T}_{\mathrm{m}}, \mathrm{T}_{2}\right)$ は若干減少するか又 はほとんど変化しない。また， $40 \% \mathrm{AN}-\mathrm{NBR}$ 試料における大きな $\mathrm{SA}$ 粒子 $\left(\mathrm{T}_{2}\right)$ は若干減少す
るにすぎない．この二つの試料は前報 ${ }^{3)} て ゙$ 自由エ ネルギー勾配論に近い場合と推定したが，大きな 粒子が若干減少するか又はほとんど変化しないこ とは必ずしも自由エネルギー勾配説の性格を明確 に表現する結果となっていない. 粒子が大きくな ればなるほど, 粒子に応力がかかり, ブルーム量 が増加するから, 時間とともに粒子径が減少する はずである．したがって，SA 粒子の時間変化か らいえることはいずれも小さい SA 粒子がブルー ムに関与し，大きく成長した粒子は $29 \%-\mathrm{NBR}$ や $40 \%-\mathrm{NBR}$ のような極性マトリックス中にお いてブルームにほとんど関与しないと考えられ る.

\section{5.まと め}

高濃度 SA の NBR 試料について, SAのブル 一ム挙動とブルーム表面のモロホルジー変化又は 内部の SAの粒子サイズ変化について検討し, 以 下の結論を得た。 


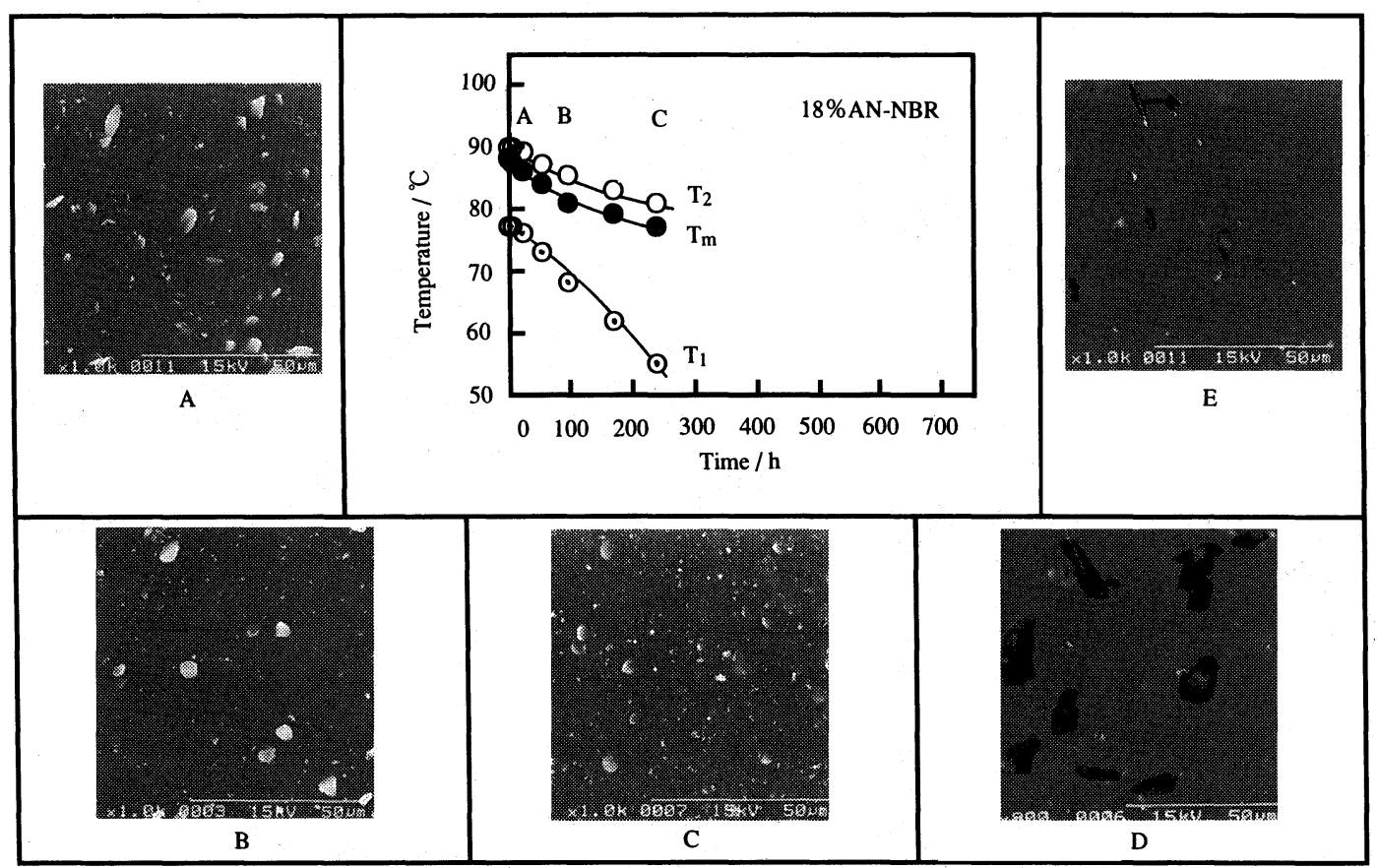

Fig. 7

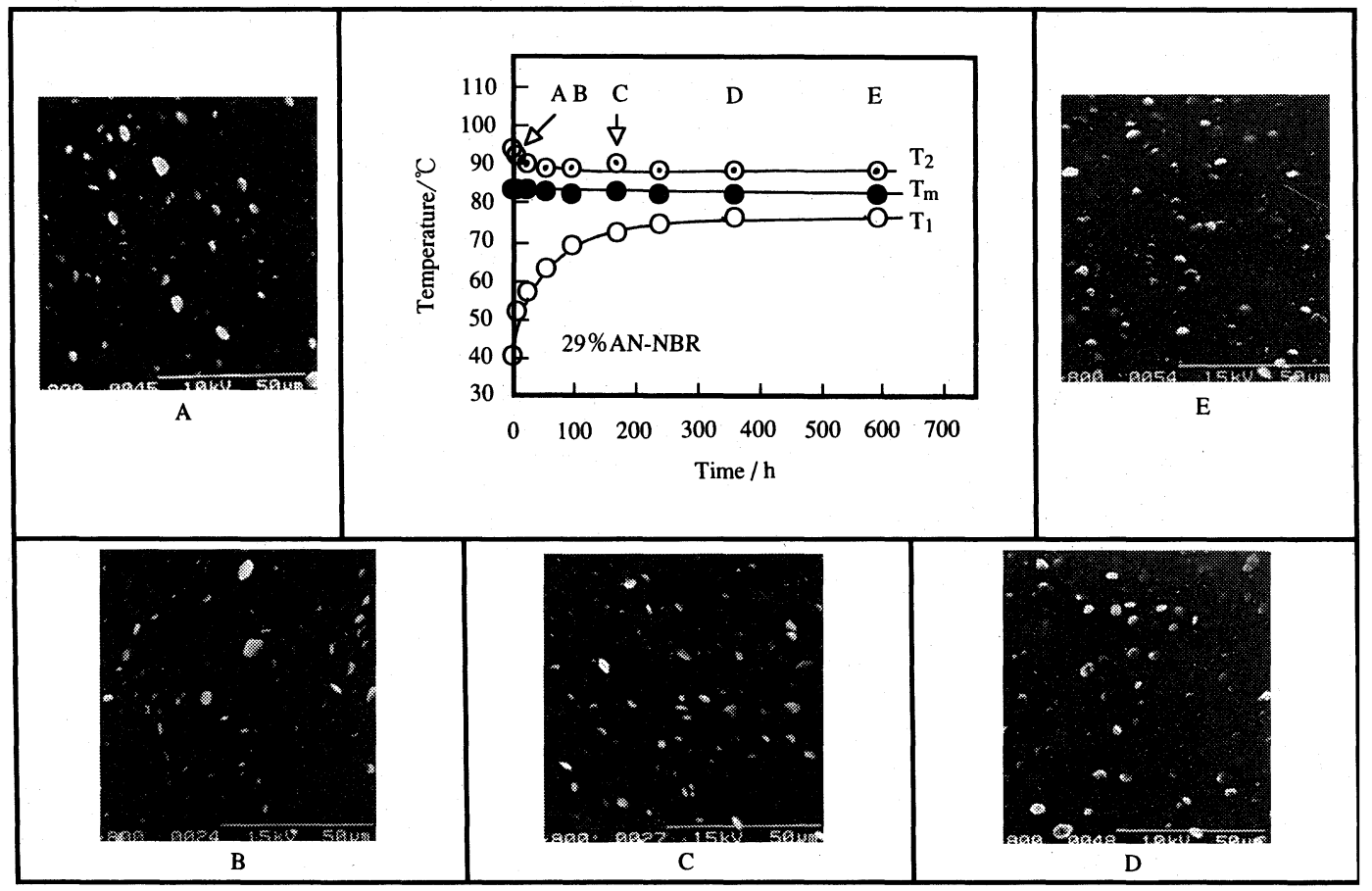

Fig. 8 


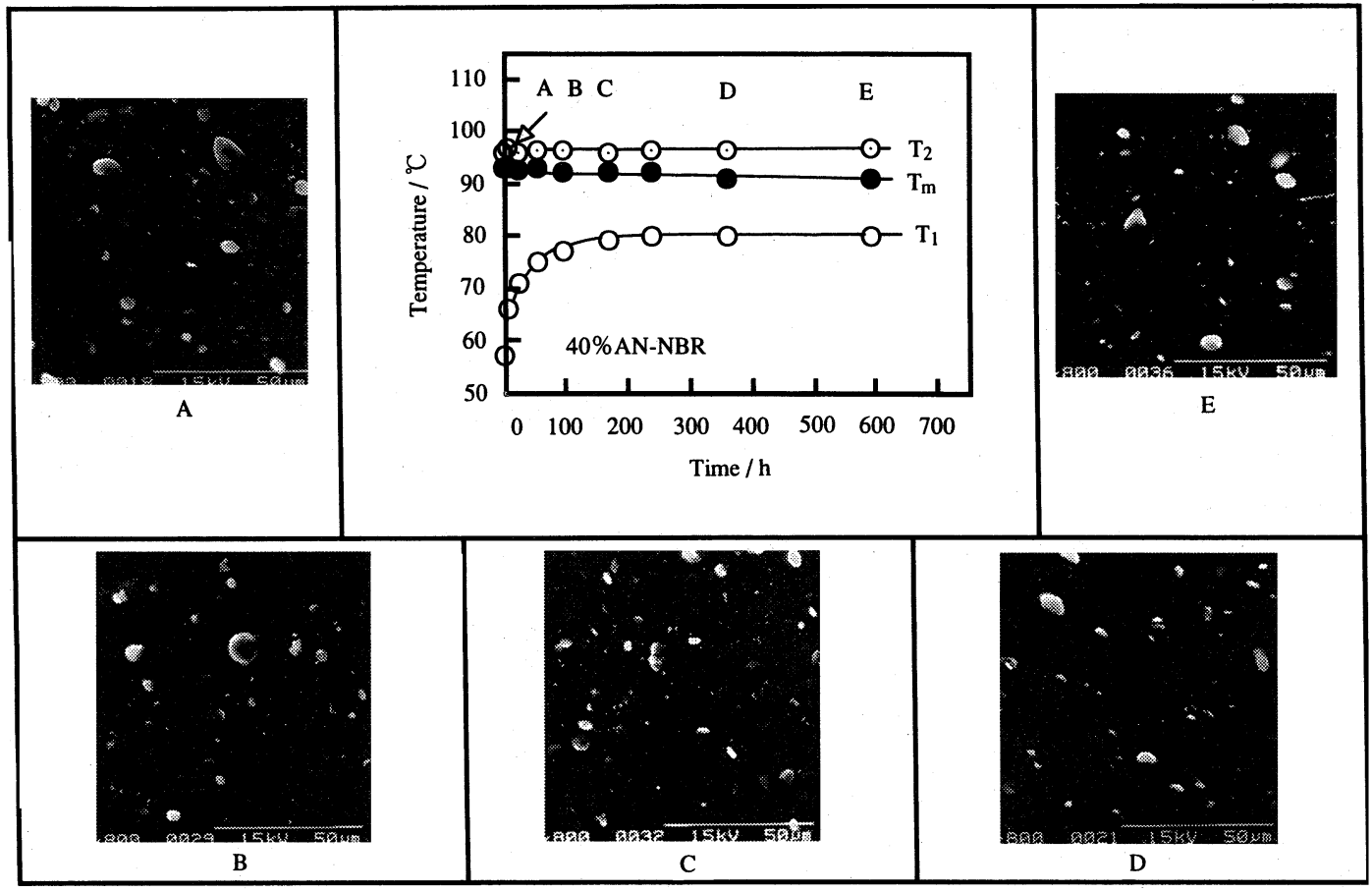

Fig. 9

1）高濃度 SA の NBR 未加硫ゴムが加硫される 過程において, 表面に初期 SA ブルーム皮膜と内 部に SA 粒子が生成することが再度確認された。 初期 NBR 加硫物試料における表面および内部の モルホロジーは NBR に対する SA の溶解性の影 響を受けなかった。

2）ブルーム皮膜の表面は $18 \% \mathrm{AN}-\mathrm{NBR}$ 試料 の場合，時間とともに小さな板状結晶から大きな 板状結晶, そして更に小さな板状結晶に変化し た.しかし $29 \% \mathrm{AN}-\mathrm{NBR} や 40 \% \mathrm{AN}-\mathrm{NBR}$ 試料のようにブルーム量が少ない場合はブルーム 表面の板状結晶から針状結晶へ変化した。

3 ) 内部の SA 粒子分布状態と SA 含有 NBR 試 料の熱分析データーの結果およびブルーム皮膜量 の関係を比較すると，18\% AN-NBR 試料は $\mathrm{SA}$ 粒子が完全にブルームしたが， $29 \% \mathrm{AN}$ $\mathrm{NBR}$ や $40 \% \mathrm{AN}-\mathrm{NBR}$ 試料は小さい $\mathrm{SA}$ 粒子 が主としてブルームに関与した。
4) 以上のように, NBR 中における SAのブル 一ム現象は表面のブルーム皮膜のモルホロジー変 化と内部の SA 粒子変化から, Williams の過飽 和理論や Nahの自由エネルギー勾配理論に基本 的に適合しない部分が存在することが分かった.

\section{参考文献}

1) Williams, I.: Rubber Chem. \& Technol., 16, 863 (1943)

2) Nah, S.H. and Thomas, A.G.: Rubber Chem. \& Technol., 54, 255(1981)

3 ) . 森 邦夫, 清水健司, 松波省一：日本ゴム協会誌, 70, 296(1997).

4）森 邦夫, 清水健司, 大越雅之, 松波省一：日本ゴム 協会誌，71，54(1998).

5 ）森 邦夫, 清水健司, 大越雅之, 松波省一：日本ゴム 協会誌, 71, 173(1998).

6 ）占部誠亮；ポリマーダイジェスト， 35，85(1983).

7 ) Dimauro, PJ., Paris, H.L. and Fath, M.A.: Rubber Chem. Technol., 52, 973(1951). 